\title{
Article \\ Cytoprotective Effects of Taurine on Heat-Induced Bovine Mammary Epithelial Cells In Vitro
}

\author{
Hui Bai ${ }^{1,2} \mathbb{D}^{\text {, Tingting }} \mathrm{Li}^{1}$, Yan Yu ${ }^{1}$, Ningcong Zhou ${ }^{2}$, Huijuan Kou ${ }^{2}$, Yingying Guo ${ }^{1}$, Liang Yang ${ }^{1}$ and \\ Peishi Yan $1, *$ (D) \\ 1 College of Animal Science and Technology, Nanjing Agricultural University, Nanjing 210095, China; \\ bbbbbhhhww@163.com (H.B.); litingtingnjau@foxmail.com (T.L.); 13382049293@126.com (Y.Y.); \\ 13436110762@163.com (Y.G.); yangliangagu@sina.com (L.Y.) \\ 2 Ulanqab Animal Husbandry Workstation, Ulanqab 012000, China; znc888@126.com (N.Z.); \\ kouhuijuan0113@126.com (H.K.) \\ * Correspondence: yanps@njau.edu.cn; Tel.: +86-13912967680
}

check for

updates

Citation: Bai, H.; Li, T.; Yu, Y.; Zhou, N.; Kou, H.; Guo, Y.; Yang, L.; Yan, P. Cytoprotective Effects of Taurine on Heat-Induced Bovine Mammary

Epithelial Cells In Vitro. Cells 2021, 10 258. https://doi.org/10.3390/ cells10020258

Received: 26 November 2020

Accepted: 25 January 2021

Published: 28 January 2021

Publisher's Note: MDPI stays neutral with regard to jurisdictional claims in published maps and institutional affiliations.

Copyright: (c) 2021 by the authors. Licensee MDPI, Basel, Switzerland. This article is an open access article distributed under the terms and conditions of the Creative Commons Attribution (CC BY) license (https:// creativecommons.org/licenses/by/ $4.0 /)$.

\begin{abstract}
It is a widely known that heat stress induces a reduction in milk production in cows and impairs their overall health. Studies have shown that taurine protects tissues and organs under heat stress. However, there have yet to be studies showing the functions of taurine in mammary alveolar cells-large T antigen (MAC-T) (a bovine mammary epithelial cell line) cells under heat shock. Therefore, different concentrations of taurine $(10 \mathrm{mM}, 50 \mathrm{mM}$, and $100 \mathrm{mM})$ were tested to determine the effects on heat-induced MAC-T cells. The results showed that taurine protected the cells against heat-induced damage as shown by morphological observations in conjunction with suppressed the translocation and expression of heat shock factor 1 (HSF1). Moreover, taurine not only reversed the decline in antioxidase (superoxide dismutase (SOD) and glutathione peroxidase (GSH-PX)) activities but also attenuated the accumulation of malondialdehyde (MDA). Meanwhile, mitochondrial damage (morphology and complex I activity) resulting from heat exposure was mitigated. Taurine also alleviated the rates of cell apoptosis and markedly depressed the mRNA expressions of BCL2 associated X, apoptosis regulator (BAX) and caspase3. Furthermore, compared with the heat stress (HS) group, the protein levels of caspase 3 and cleaved caspase 3 were decreased in all taurine groups. In summary, taurine improves the antioxidant and anti-apoptosis ability of MAC-T cells thereby alleviates damage of cells due to heat insults.
\end{abstract}

Keywords: MAC-T cells; taurine; heat stress; mitochondrial damage; oxidative stress; cell apoptosis

\section{Introduction}

With the global temperature continuously rising, the negative impact of the greenhouse gas emissions on animal husbandry is increasingly intensified [1]. Heat stress, as a major environmental stressor, brings major challenges to the dairy industry [2], with previous studies reporting that heat stress not only decreases the milk production but also impairs the health of cows, including by increasing somatic cell counts and metabolic disorders occurrence [3,4]. Therefore, heat stress causes great economic loss to the dairy industry [5,6]. Meanwhile, the metabolism of mammary epithelial cells is also changing dramatically [7]. In one study, it was found that, compared with a thermoneutral group, there were 2716 markedly differently expressed genes in the bovine mammary epithelial cells of the heat-treated group [8]. Accumulating evidence indicates that heat stress is associated with a change in cell junction [9], decreasing cell viability, increasing oxidative stress, and increasing cell apoptosis [10]. Therefore, it is of vital significance to identify effective means to mitigate the damage caused by heat stress.

A variety of research has been directed toward enhancing the functions of the mammary gland under high ambient temperatures to steadily maintain the lactation of the mammary epithelial cells $[11,12]$. Taurine is recognized to be a beta-amino ethanesulfonic 
acid, which can be found to exist as a free state in all animal tissues. Moreover, taurine has many biological and pharmacological functions [13] and is considered to be a strong antioxidant. Extensive research has shown that taurine improves antioxidant levels, such as superoxide dismutase (SOD), glutathione peroxidase (GSH-PX), as well as catalase (CAT) $[14,15]$. Previous studies have also focused on the importance of taurine in terms of its anti-apoptosis effect, with one study indicating taurine markedly hampered increases in the expression of Bax, Caspase9, Caspase3, Cytochrome c (Cyt-c) and P53 in broiler aortic endothelial cells under heat shock [16]. Furthermore, the taurine additive has been reported to have anti-inflammatory effects $[17,18]$, as well as treating intractable diseases, such as Alzheimer's disease [19]. Thus, taurine appears to be an attractive candidate for use as a cytoprotector and heat-induced mitigators; therefore, it seems to be a reasonable hypothesis that taurine may attenuate heat-induced dysfunction in cow mammary epithelial cells.

However, to the best of our knowledge, no report has yet documented any effects of taurine in mammary alveolar cells-large T antigen (MAC-T) cells under heat exposure. Therefore, the aim of this study was to investigate the effects of taurine supplementation on the expressions of genes and proteins related to oxidative stress and apoptosis under control and heat stress conditions in order to investigate the roles of taurine and its mechanism of action in mitigating heat-induced damage caused to MAC-T cells.

\section{Materials and Methods}

\subsection{Chemicals}

Taurine (suitable for cell culture, meets USP testing specifications) was purchased from Sigma Chemical Co. (St. Louis, MO, USA).

\subsection{Cell Culture and Treatment}

MAC-T (a bovine mammary epithelial cell line) cells (a gift from associate researcher G. Xing, Jiangsu Academy of Agricultural Sciences) were incubated in Dulbecco's modified Eagle's medium (DMEM)/Ham's F-12 medium (Hyclone, Logan, UT, USA) with 10\% fetal bovine serum (FBS) (ScienCell, Carlsbad, CA, USA) and $200 \mathrm{U} / \mathrm{mL}$ of penicillin and streptomycin (Hyclone, Logan, UT, USA). The cells were cultured at $37{ }^{\circ} \mathrm{C}$ in a humidified atmosphere containing $5 \% \mathrm{CO}_{2}$.

The cells were divided into five groups through randomization: A control (C) group, heat stress (HS) group, low taurine (HS + LTau) group, moderate taurine (HS + MTau) group, and high taurine (HS + HTau) group. After the cells reached $70 \%$ confluence, prior to heat treatment, they were cultured for $24 \mathrm{~h}$ under DMEM/F12 with serum-free conditions. Then, the HS group was cultured at $42.5^{\circ} \mathrm{C}$ for one hour and recovered at $37^{\circ} \mathrm{C}$ for another $12 \mathrm{~h}$; the taurine groups were pretreated with $10 \mathrm{mM}, 50 \mathrm{mM}, 100 \mathrm{mM}$ of taurine for two hours followed by culturing at $42.5^{\circ} \mathrm{C}$ for one hour and recovery at $37^{\circ} \mathrm{C}$ for $12 \mathrm{~h}$. The $\mathrm{C}$ group was continuously cultured in $37^{\circ} \mathrm{C}$ and received no taurine treatment.

\subsection{Cell Viability}

Cell viability was quantified by 3-(4,5-dimethylthiazol-2-yl)-2,5-diphenyltetrazolium bromide (MTT) medium (KeyGEN BioTECH, Nanjing, China). The MAC-T cells were seeded in 96-well plates prior to incubating for one hour or not at $42.5^{\circ} \mathrm{C}$; then, the cells were recovered at $37^{\circ} \mathrm{C}$ for different amounts of time. Additionally, the cells were treated with various concentrations of taurine $(0,10,50,100$, and $200 \mathrm{mM})$ for two hours and then cultured for another $12 \mathrm{~h}$. According to the instruction, $50 \mu \mathrm{L}$ of the $1 \times$ MTT solution (1:4 diluted with dilution buffer) was added to each well, and the cells were maintained for four hours at $37^{\circ} \mathrm{C}$ containing $5 \% \mathrm{CO}_{2}$. Then, $150 \mu \mathrm{L}$ of dimethyl sulfoxide (DMSO) (Sigma, St. Louis, MO, USA) was added, and the plates were oscillated before measuring the $\mathrm{OD}$ at $550 \mathrm{~nm}$ using a microplate reader. 


\subsection{Ultrastructural Observation}

The MAC-T cells were seeded into six-well plates and treated as described above. Then, $2 \mathrm{~mL}$ of $2.5 \%$ glutaraldehyde fixative was added into each well. The cells were scraped gently and collected into the centrifuge tubes. Then, the samples were removed from the fixing solution and rinsed three times with phosphate buffer (PBS) before administering $1 \%$ osmium tetroxide for postfixing. After dehydration, infiltration, and embedding, the samples were cut into ultrathin $(60-80 \mathrm{~nm})$ sections and stained with uranyl acetate and lead citrate. Then, the samples were observed with a transmission electron microscope (HT7700, Hitachi, Tokyo, Japan).

\subsection{Detection of Mitochondrial Complex I Activity}

Mitochondrial complex I activity was estimated via the colorimetric method using commercial kits (Nanjing Jiancheng Bioengineering Institute, Nanjing, China). The determination consisted of three steps: Background control determination, total activity determination, and non-specific activity determination. Mitochondrial proteins were extracted with a mitochondrial protein extraction kit (Nanjing Jiancheng Bioengineering Institute, Nanjing, China), and complex I activity was quantified in the mitochondria.

\subsection{Antioxidant Capacity Measurement}

The cells were cultured in six-well plates for $48 \mathrm{~h}$ prior to heat-induced treatment; then, they were treated and harvested. The oxidative parameters (SOD, GSH-PX, and MDA) were detected using the corresponding commercial kits (Nanjing Jiancheng Bioengineering Institute, Nanjing, China). Furthermore, the protein concentration was detected using a protein assay kit (Nanjing Jiancheng Bioengineering Institute, Nanjing, China) in accordance with the manufacturer's instructions. Then, we used a microplate reader to measure the absorbance of each well.

\subsection{Detection of Apoptosis}

Cell apoptosis was assessed using an Annexin V-fluorescein isothiocyante (FITC) /propidium iodide (PI) apoptosis detection kit (Absin Biochemical Company, Shanghai, China). According to the manufacturer's recommendation, the cells were treated as indicated before being harvested and then washed twice with cold PBS. Following this, $300 \mu \mathrm{L}$ of $1 \times$ binding buffer (1:9 diluted with binding buffer) was added to suspend the cells. The cells were stained with $5 \mu \mathrm{L}$ of Annexin V-FITC and $5 \mu \mathrm{L}$ of PI in each tube. Before the analysis, we added $200 \mu \mathrm{L}$ of the $1 \times$ binding buffer to each well. Finally, cell apoptosis was analyzed with a FACS Calibur (BD Biosciences, Bedford, MA, USA) flow cytometer (FCM), and $1 \times 10^{4}$ cells were detected for each tube at minimum. The results were analyzed using FlowJo software.

\subsection{RNA Isolation and Quantitative Real-Time PCR ( $q P C R$ )}

The total RNA was extracted with a Trizol reagent (Invitrogen, Carlsbad, CA, USA) and reversed transcribed with a PrimeScript RT reagent (Takara, Tokyo, Japan). The purity of the total RNA and cDNA was measured by a nanodrop spectrophotometer. Primers were designed by the National Center for Biotechnology Information (NCBI) PrimerBLAST and synthesized by a commercial corporation (Sangon Biotech, Shanghai, China), as shown in Table 1. Ribosomal protein S15 (RPS15), ribosomal protein S9 (RPS9), and ubiquitously expressed prefoldin like chaperone (UXT) were used as housekeeping genes. The mixtures (cDNA products, premix EX Taq, primers, ROX, and water) were performed in a quantstudio 5 real-time PCR instrument (Applied Biosystems, Carlsbad, CA, USA) using a SYBR premix EX Taq kit (Takara, Tokyo, Japan). The $2^{-\Delta \Delta C t}$ method was applied to calculate the relative mRNA abundance. 
Table 1. Sequences of primers for the real-time PCR assay.

\begin{tabular}{lll}
\hline Genes & GenBank Number & Primer Sequence $\mathbf{( 5}^{\prime}$-3 $\left.^{\prime}\right)$ \\
\hline RPS9 & NM_001101152.2 & $\begin{array}{l}\text { Forward: TCTTGGTTTCCAGAGCGTTG } \\
\text { Reverse: ATACTCGCCGATCAGCTTCA }\end{array}$ \\
\hline UXT & NM_001037471.2 & $\begin{array}{l}\text { Forward: CGCTACGAGGCTTTCATCTCT } \\
\text { Reverse: CGAGTGGTTAGCTTCCTGGAG }\end{array}$ \\
\hline RPS15 & NM_001024541.2 & $\begin{array}{l}\text { Forward: CAAGATGGCGGAAGTGGAAC } \\
\text { Reverse: GTAGCTGGTCGAGGTCTACG }\end{array}$ \\
\hline BCL2 & NM_173894.1 & $\begin{array}{l}\text { Forward: CTGAGCGAGTGTCTGAAGCG } \\
\text { Reverse: ACAGCTGCGATCATCCTCTG }\end{array}$ \\
\hline Caspase3 & XM_015473877.2 & $\begin{array}{l}\text { Forward: AGGCTGGGACGCCTTTG } \\
\text { Reverse: GGGCTTCACTTATGGCCCAG }\end{array}$ \\
\hline HSF1 & NM_001076809.1 & $\begin{array}{l}\text { Forward: TGGCGAAATGCAAAGAACGG } \\
\text { Reverse: TGTGAGCGTGCTTTTCAGC }\end{array}$ \\
\hline HSP90 & NM_008302.3 & $\begin{array}{l}\text { Forward: AGCACGCCCAGCAACAGAAAG } \\
\text { Reverse: CCGCCGTCGTTCAGCATCAG }\end{array}$ \\
\hline
\end{tabular}

\subsection{Immunofluorescent Staining}

The cells were cultivated in six-well plates $48 \mathrm{~h}$ before treatment. After heat exposure, they were washed two times with PBS and fixed in $1 \mathrm{~mL} \mathrm{4 \%}$ paraformaldehyde for $15 \mathrm{~min}$. After permeabilizing and blocking, primary antibody: Heat shock factor 1 (HSF1) (dilution 1:200, Proteintech, Wuhan, China) was added, and the samples were incubated for $12 \mathrm{~h}$ at $4{ }^{\circ} \mathrm{C}$. After three washes with PBS, the cells were incubated with a secondary antibody for $50 \mathrm{~min}$ at room temperature. Then, after washing again, the nucleus were stained with $4^{\prime}$,6-diamidino-2-phenylindole dihydrochloride (DAPI) for $10 \mathrm{~min}$. Subsequent imaging and analysis of the samples were performed using a fluorescence microscope (Zeiss, Oberkochen, Germany).

\subsection{Western Blotting Assay}

The protein expressions of HSF1, heat-shock protein 90 (HSP90), caspase3, and cleaved caspase 3 were examined via western blot assay. The cells were lysed with RIPA buffer for $30 \mathrm{~min}$ on the ice and centrifugated at $12,000 \mathrm{rpm}$ for $10 \mathrm{~min}$ at $4{ }^{\circ} \mathrm{C}$. Then, the supernatants were collected as the total protein solution. Proteins were determined using a BCA protein quantification kit (Nanjing Jiancheng Bioengineering Institute, Nanjing, China) according to the manufacturer's instructions. Proteins were denatured by heating. Then, the lysates were separated, transferred, and blocked by $5 \%$ milk. In accordance with the antibody instructions, membranes were incubated overnight at $4{ }^{\circ} \mathrm{C}$ with the following primary antibodies: HSF1 (1:1000, Proteintech, Wuhan, China), HSP90 (1:2000, Proteintech, Wuhan, China), caspase3 (1:400, Proteintech, Wuhan, China). The membranes were washed three times, and then the secondary antibodies were added for $30 \mathrm{~min}$ and diluted at a ratio of 1:3000. The protein bands were detected with a luminescent image analyzer (Fujifilm, Tokyo, Japan) using an enhanced chemiluminescence (ECL) substrate (Thermo Scientific, Waltham, MA, USA). Finally, western blotting results were quantified using ImageJ software (National Institutes of Health, Bethesda, MD, USA).

\subsection{Statistical Analysis}

All measurements were performed in triplicate, and all data was expressed as the mean \pm standard error of the mean (SEM). Statistical analysis was performed with one-way ANOVA followed by the least significant difference (LSD) method for multiple comparisons. 
All statistical tests were carried out by SPSS 21.0 (IBM, New York, NY, USA), with $p<0.05$ considered as statistically significant. ${ }^{*} p<0.05,{ }^{* *} p<0.01$, and ${ }^{* * *} p<0.001$.

\section{Results}

\subsection{Cell Viability and Change in Cell Morphology of Mammary Epithelial Cells after} Heat-Induced Treatment

In order to explore the most appropriate time point for treating the MAC-T cells, the cells were exposed to heat shock for one hour, and recovered at $37^{\circ} \mathrm{C}$ for different durations. As shown in Figure 1A, the cell viability gradually decreased within $12 \mathrm{~h}$ recovery time, causing about a $40 \%$ decrease in cell viability $(p<0.001)$. However, the cell viability almost fully recovered at $24 \mathrm{~h}$. In addition, when the cells were treated with 0-200 $\mathrm{mM}$ taurine (Figure 1B) for two hours followed by cultivation for another $12 \mathrm{~h}$, no significant impact of the cell viability was observed up to $200 \mathrm{mM}$ taurine (Figure 1C). Hence, we treated the cells at $12 \mathrm{~h}$ recovery time with three different doses of taurine $(10 \mathrm{mM}, 50 \mathrm{mM}$, and $100 \mathrm{mM}$ ) to investigate the effects of taurine on heat-induced MAC-T cells.

A

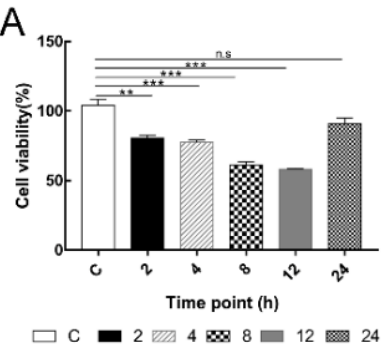

D
B<smiles>NCCS(=O)(=O)O</smiles>

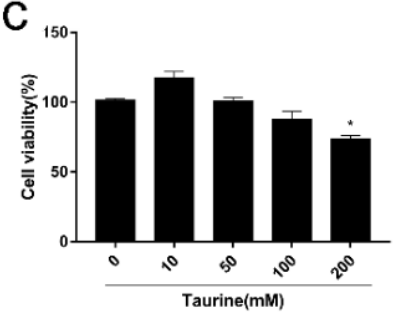

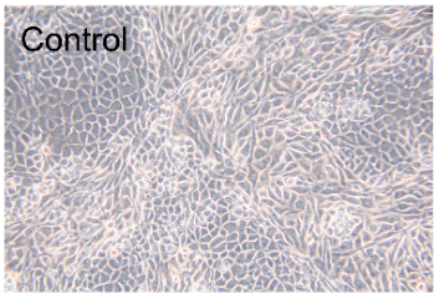

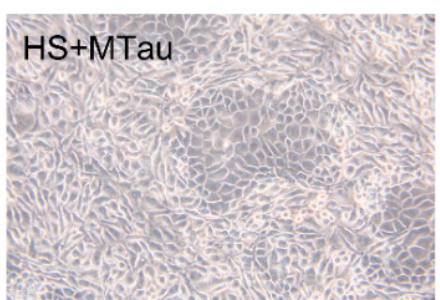

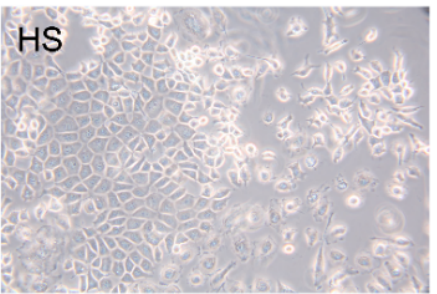

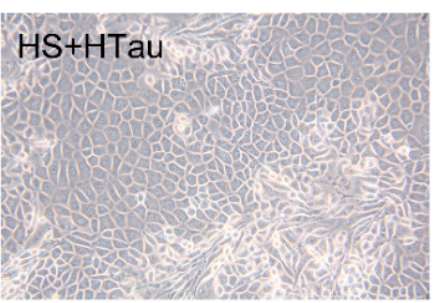

Figure 1. Effects of taurine supplementation on the cell viability and cell morphology of mammary alveolar cells-large T antigen (MAC-T) cells. (A) cell viability induced by heat shock on MAC-T cells, (B) chemical structure of taurine, (C) cell viability when treated with different concentrations of taurine for two hour and then recovered for another $12 \mathrm{~h}$, and (D) phase-contrast micrographs of MAC-T cells were exposed to heat stress with and without taurine. Magnification $200 \times .{ }^{*} p<0.05$, ** $p<0.01$, and ${ }^{* * *} p<0.001$.

Cell morphology was also observed with an inverted light phase-contrast microscope. Cells in the $C$ group had a normal shape. In contrast, some cells exhibited abnormal cell junction and shape in the HS group, which coalesced into a mass. Interestingly, $50 \mathrm{mM}$ and $100 \mathrm{mM}$ taurine protected the morphology of the MAC-T cells against heat-induced alteration (Figure 1D).

\subsection{Taurine Alleviates Heat Shock Response in MAC-T Cells}

Moreover, we researched whether taurine played a role in the heat-induced treatment that triggered the heat shock response of MAC-T cells. As shown in Figure 2A, the heat 
shock response of the cells was activated for essential survival under heat exposure. The transcriptions of HSF1 and HSP90 were significantly enhanced. Then, we studied the translocation of HSF1 from the cytoplasm to the nucleus, and Figure 2B indicated that cells in the C group exhibited low levels of HSF1, while the cells in the HS group showed higher levels of HSF1 in both the cytoplasm and the nucleus, and taurine suppressed the translocation of HSF1. In addition, the mRNA expression levels and protein levels of HSF1 were increased in the HS group compared with the $\mathrm{C}$ group, while they were markedly decreased in all taurine groups. The change in the mRNA expression abundance of HSP90 was consistent with that of HSF1; however, the protein expression of HSF90 was not significant between groups (Figure 2E).

A

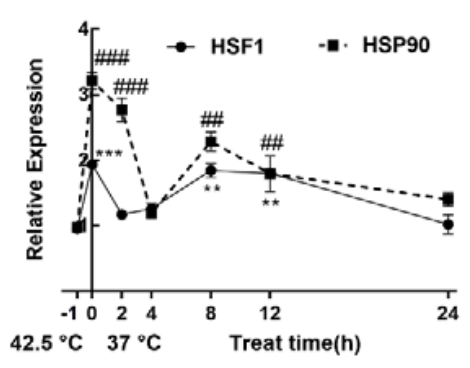

C

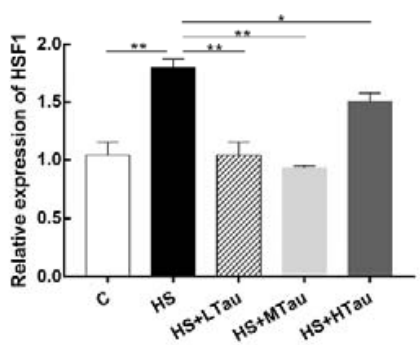

D

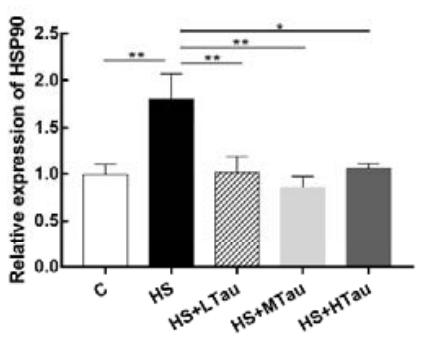

E

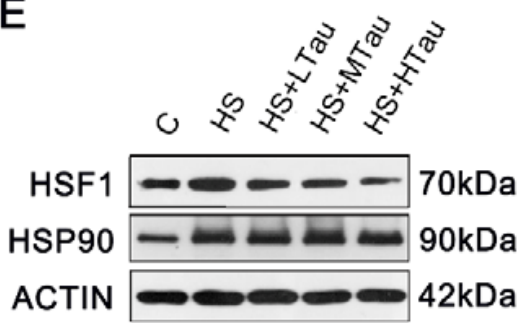

B
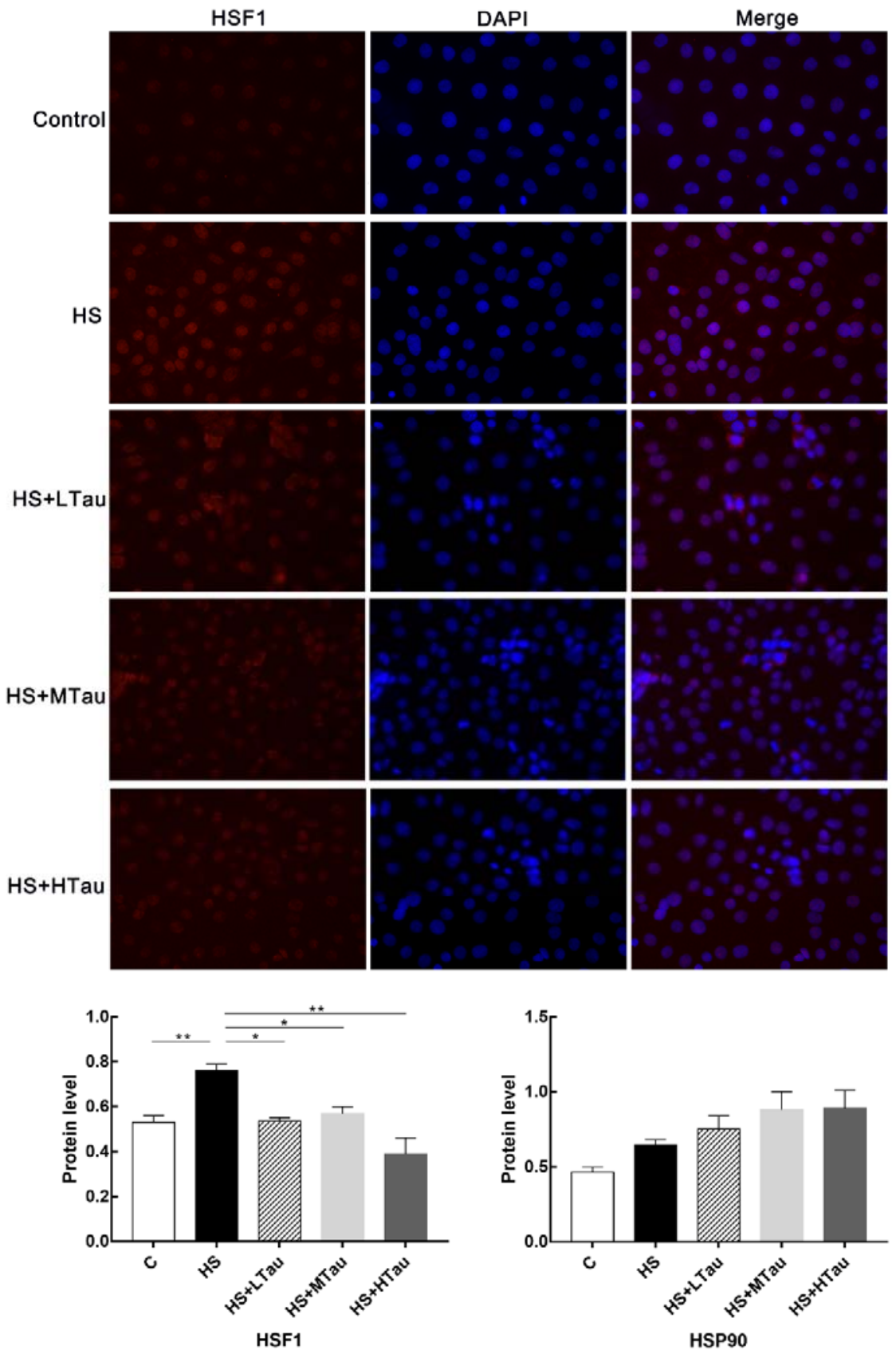

Figure 2. The role of taurine in MAC-T cells in response to heat shock. (A) the transcriptions of heat shock factor 1 (HSF1) and heat-shock protein 90 (HSP90) changes with the recovery time, (B) the translocation of HSF1. Magnification 400× (C) HSF1 mRNA levels, (D) HSP90 mRNA levels, and (E) HSF1 and HSP90 protein levels. All data are presented as the mean \pm SEM. ${ }^{*} p<0.05,{ }^{* *} p<0.01,{ }^{* * *} p<0.001, \# \#<0.01$, \#\#\# $p<0.001$. 


\subsection{Taurine Relieves Structural Damage and the Decline in the Complex I Activity of Mitochondria under Heat Shock}

In addition, to further study the function of taurine on the intracellular structure of heat-induced MAC-T cells, ultrastructural alterations were observed using a transmission electron microscope. As shown in Figure 3A, the $\mathrm{C}$ group displayed a complete structure and rich cristae in the mitochondria. The mitochondrial morphology was markedly changed under heat stress, with observations such as the swollen structure of the mitochondria with the loss of the cristae in the HS group. Furthermore, $10 \mathrm{mM}$ and $50 \mathrm{mM}$ of taurine effectively attenuated the structural damage done to the mitochondria. Moreover, mitochondrial complex I activity was suppressed $(p<0.05)$ by heat exposure, and was markedly elevated in the HS + LTau group $(p<0.05)$ (Figure 3B).

\section{A}
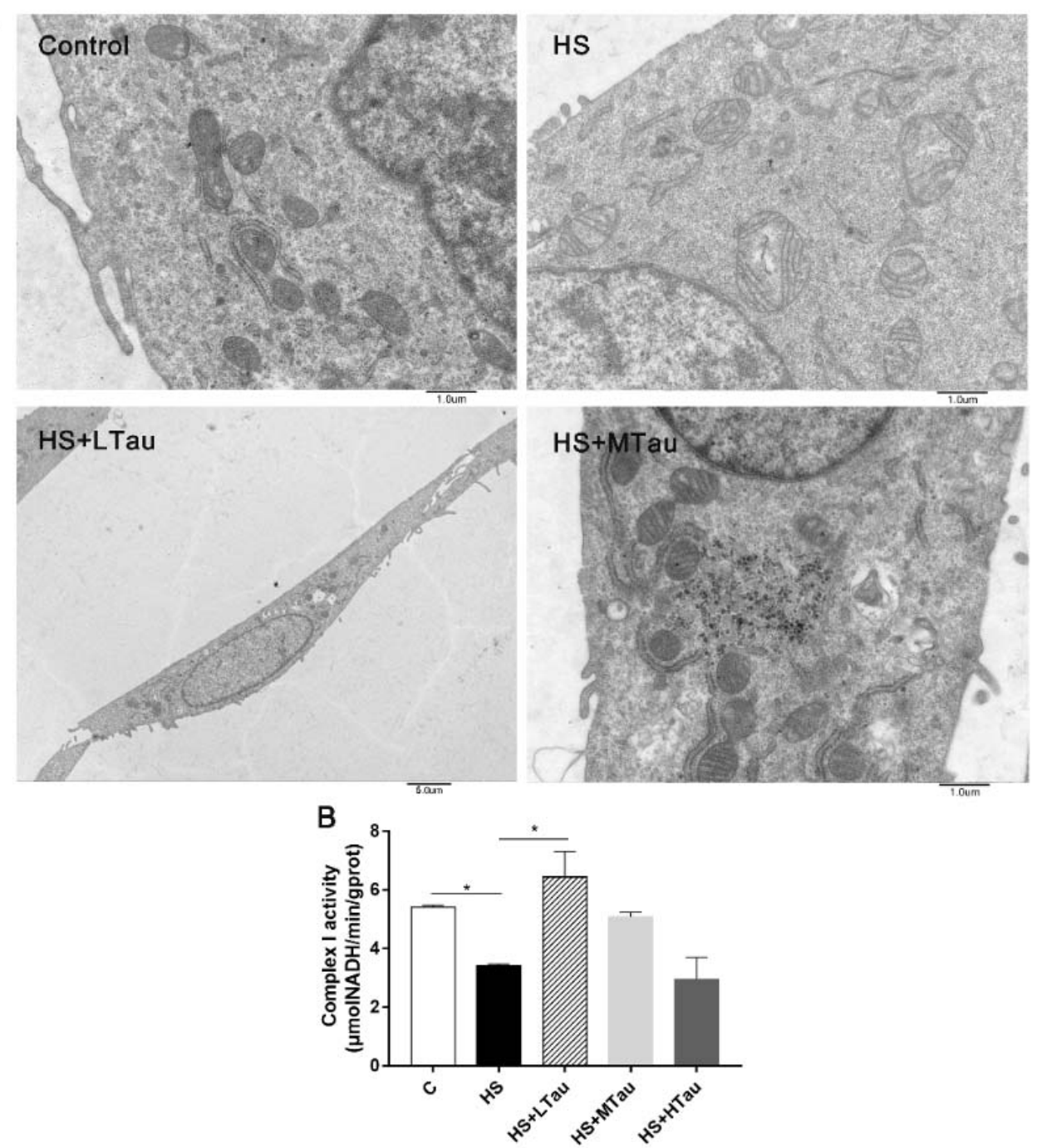

Figure 3. Taurine supplementations relieve the damage done to the mitochondrial structure and the decline in complex I activity in MAC-T cells under heat exposure. (A) the mitochondrial structures and (B) mitochondrial complex I activity. Transmission electron microscopy images at original magnifications of $\times 8000$ Control, heat stress (HS), and moderate taurine (HS + MTau), and $\times 2000$ low taurine (HS + LTau). ${ }^{*} p<0.05$. 


\subsection{Taurine Enhances Antioxidant Capacity of Heat-Induced MAC-T Cells}

To investigate whether taurine can affect the antioxidant capacity of MAC-T cells induced by high-temperature, some antioxidant parameters were detected in this study. Our results showed that the MDA level was significantly higher in the HS group than in the $\mathrm{C}$ group $(p<0.01)$, and the activities of SOD and GSH-PX were reduced in the HS group compared to in the $C$ group $(p<0.01)$. The MAC-T cells in the taurine groups exhibited lower levels of MDA than in the HS group $(p<0.01)$ (Figure 4B). In addition, there was no marked difference in the SOD activity between the HS and HS + LTau groups; however, the activities of SOD in the HS + MTau group and HS + HTau group were significantly higher than in the HS group (Figure 4A). Similarly, pretreatment with $10 \mathrm{mM}$ taurine reversed the activities of GSH-PX in the HS-induced MAC-T cells, while the other two groups showed no effect (Figure 4C). In summary, heat stress associated with oxidative damage was effectively declined by taurine.

A

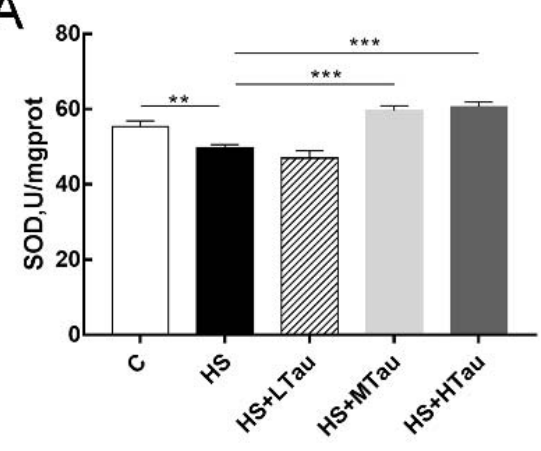

B

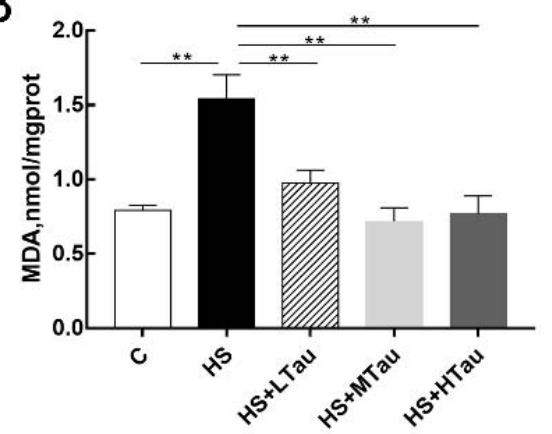

C

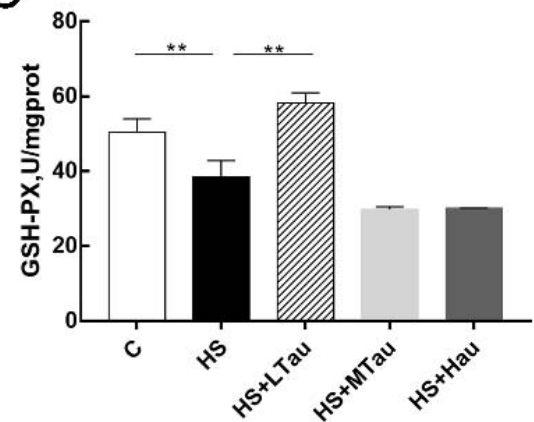

Figure 4. Taurine improved the activities of antioxidant enzymes and the antioxidant capacity of heat-induced MAC-T cells. (A) the activity of superoxide dismutase (SOD), (B) malondialdehyde (MDA) production, and (C) glutathione peroxidase (GSH-PX) activity. ${ }^{* *} p<0.01$, and ${ }^{* * *} p<0.001$.

\subsection{Taurine Reduces Cell Apoptosis Induced by Heat Shock}

We next investigated whether taurine could also relieve the level of cell apoptosis in heat-induced MAC-T cells. The rates of cell apoptosis were detected with an Annexin V-FITC/PI detection kit, and the results were shown in Figure 5A. The ratio of cell apoptosis increased markedly when the MAC-T cells were treated with heat shock $(p<0.001)$. The $10 \mathrm{mM}, 50 \mathrm{mM}$, and $100 \mathrm{mM}$ of taurine treatments all significantly alleviated cell apoptosis in the heat shock-induced MAC-T cells. In addition, compared to the HS group, the mRNA abundance of BCL2 associated X, apoptosis regulator (BAX) (a pro-apoptosis marker), caspase3 (a pro-apoptosis marker), and the ratio of BAX/BCL2 apoptosis regulator (Bcl-2) were markedly decreased in all taurine groups (Figure 5C,E,F), while there was no significant difference with the $C$ group. Furthermore, compared with the HS group, the protein expressions of caspase 3 and cleaved caspase 3 declined with all taurine treatmentsbut at varying degrees (Figure $5 \mathrm{G}$ ). Therefore, taurine may play an anti-apoptotic role by rescuing cells under heat exposure. 
A

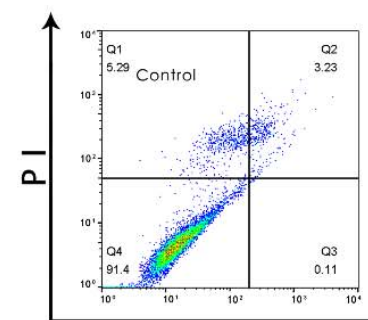

B

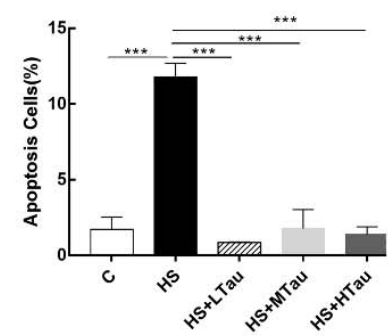

$\mathrm{E}$

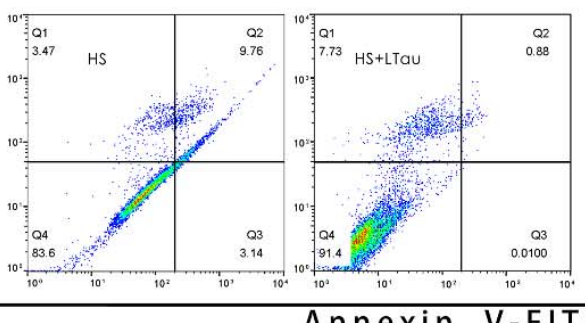

C

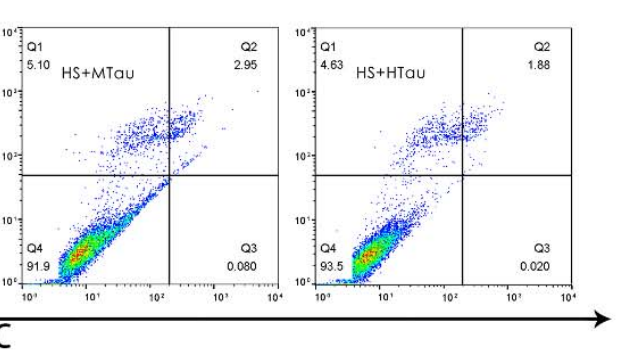

D
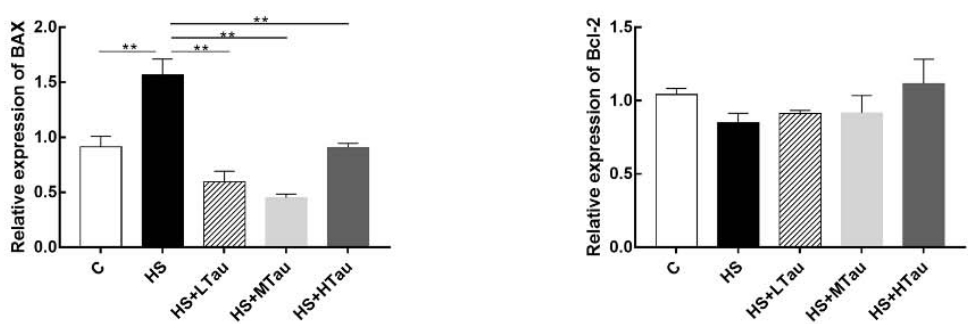

$\mathrm{F}$

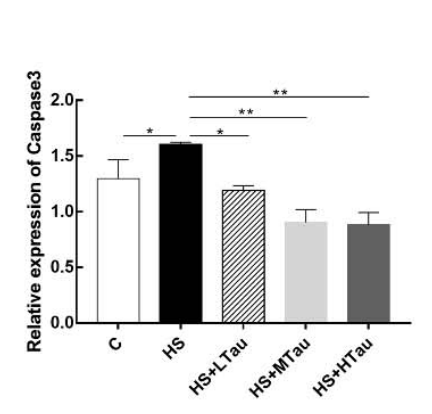

G

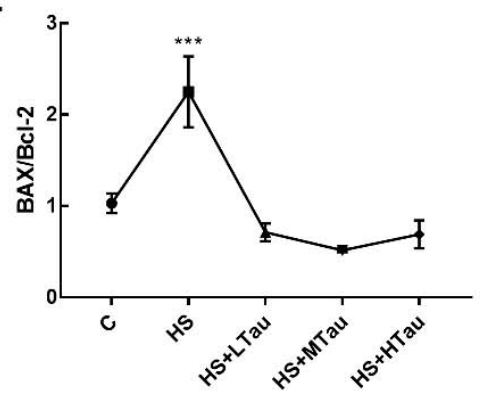

\section{$F$}
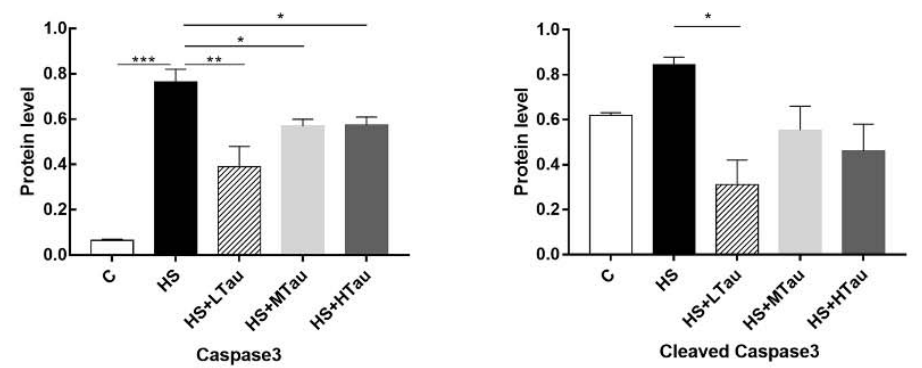

Figure 5. Taurine pretreatments attenuated cell apoptosis in MAC-T cells under heat exposure. (A) effects of taurine on apoptosis in MAC-T cells induced by heat shock analyzed via flow cytometry. (B) cell apoptosis rates. (C) mRNA abundance of BCL2 associated X, apoptosis regulator (BAX). (D) mRNA abundance of BCL2 apoptosis regulator (Bcl-2). (E) the ratio of BAX/Bcl-2. (F) mRNA abundance of caspase3. (G) the protein expression of caspase3 and cleaved caspase3 were determined by Western blotting. All data are presented as the mean \pm SEM. ${ }^{*} p<0.05 ;{ }^{* *} p<0.01 ;{ }^{* * *} p<0.001$.

\section{Discussion}

Earth's increasing temperature has had a major impact on the dairy industry, including reducing productivity $[20,21]$, increasing metabolic disorders prevalence, and even enhancing mortality [22]. Furthermore, heat stress induces oxidative stress, apoptosis, and other series of events in cow mammary epithelial cells in vitro [23,24]. Many studies have focused on identifying additives that can relieve the damage caused by heat shock. Taurine was first isolated from ox bile, which has a wide variety of biological and pharmacological activities [13]. Many previous studies have shown taurine as a kind of antioxidant [25], a nutritional supplementation [26], that is strong when focused on minimizing the severity of various diseases caused by oxidative damage and many kinds of stress $[19,27,28]$. Although 
there are many studies on taurine, there have been none-until now-investigating its molecular mechanism in bovine mammary epithelial cells under heat stress. This study was thus the first to clarify the effects of taurine pretreatments in heat-induced MAC-T cells, which were cultivated at $42.5^{\circ} \mathrm{C}$ for one hour and recovered at $37^{\circ} \mathrm{C}$ for $12 \mathrm{~h}$.

Previous cell culture-based studies have investigated that the cell viability of heatinduced bovine mammary epithelial cells (BMECs) is the lowest when cells are recovered for $12 \mathrm{~h}$ at $37^{\circ} \mathrm{C}$ [24], which is consistent with the results of our present study. Furthermore, it has been indicated that a considerable additional dosage of taurine has been used from 1 to $100 \mathrm{mM}$ concentrations [29]. In this study, we used 0-200 $\mathrm{mM}$ of taurine to study taurine's effects on cell viability and found that pretreatment with taurine became toxic when the concentration reached $200 \mathrm{mM}$. Therefore, this study was designed to study the dosages of $10 \mathrm{mM}, 50 \mathrm{mM}$, and $100 \mathrm{mM}$.

When cells survive under heat exposure, their heat shock response is activated. The overexpression of heat shock protein (HSP) is triggered by HSF1. HSF1, which separates with HSPs (HSP90 for the most part), enters the nucleus and induces the expression of downstream heat shock element regulatory genes [30]. Our data indicated that the heat stress upregulated the mRNA expression abundance of HSF1 and HSP90. With the different recovery times, the expression level fluctuated [31]. Furthermore, the translocation of HSF1 from the cytoplasm to the nucleus also increased in the MAC-T cells under heat shock. In contrast, all the different taurine supplementation levels reduced the translocation of HSF1 and suppressed the mRNA abundance and protein levels of HSF1. However, taurine had no effect on the protein expression of HSP90. These findings were consistent with the study of Belal in terms of the role of taurine in the mRNA and protein expression levels of HSP90 in liver tissue [32]. Future studies are needed to identify the levels of other HSPs under heat stress and further determine the effects of taurine. The present study indicated that taurine improved the thermotolerance of the MAC-T cells by reducing the translocation and the protein level of HSF1 in order to prevent the expression of downstream heat shock element regulatory genes in heat-induced MAC-T cells.

It is widely accepted that mitochondrial functions depend on the integrity of mitochondria. Mitochondrial calcium influx is triggered when it suffers an attack. Then, the mitochondrial nucleases are activated to indiscriminately degrade all mitochondrial polynucleotides [33]. In this study, ultrastructural observation showed that heat exposure could damage the mitochondrial structure, but, when the cells were pretreated with different concentrations of taurine, this damage was relieved. Moreover, the mitochondrial complex I activity in the HS + LTau group was elevated to resist mitochondrial dysfunction. These results were supported by those of Zhuang, studying in chronic heat-stressed broilers [34], and Jong, studying cardiomyocytes [35].

Meanwhile, the present study provided insight into the role of taurine as an antioxidant. The steady-state concentrations of pro-oxidants and antioxidants are disturbed, which induces oxidative stress in cells [36]. Traditionally, SOD and GSH-PX are the main antioxidant defense systems in cells and are associated with the antioxidant capacity of cells [37]. Heat stress has been considered to decrease the activities of SOD [23,24] and GSH-PX [34], while MDA (a last product of lipid peroxidation) levels have been increased under heat shock in many previous studies $[23,24,38]$. Consistently, taurine can rescue oxidative stress by restoring the activity of SOD and decreasing the level of MDA in the present study. Interestingly, compared with the HS group, taurine significantly decreased the levels of GSH-PX only in the HS + LTau group [39], which suggested that it perhaps depended on the taurine dosage. Several studies have proposed that taurine decreases oxidative stress by forming a conjugate (5-taurinomethyluridine) with a key uridine moiety in the wobble position of mitochondrial tRNALeu (UUR), the deficiency of which leads to the defective assembly of respiratory chain complex I, resulting in the cell undergoing oxidative stress; this then indicates that taurine played a vital role in attenuating the oxidative stress $[35,40]$. 
It is demonstrated that heat stress can trigger oxidative stress $[23,24]$, and exposure to oxidative stress induces a wide series of responses, such as apoptosis and, finally, necrosis $[41,42]$. In the present study, the taurine pretreatment groups exhibited significantly declined the rates of apoptosis when compared with the HS group. The mRNA expression levels of BAX and caspase 3 were markedly lower than those of the HS group. Moreover, the ratio of $\mathrm{BAX} / \mathrm{Bal}-2$ was decreased significantly. Furthermore, the protein levels of caspase 3 and cleaved caspase 3 in the HS + LTau, H S+ MTau, and HS + HTau groups were decreased when compared with those of the HS group. These results were line with the studies of Kai Liu in porcine kidney-15 cells [43] and Yan Li in PC12 cells [29]. Based on the above investigations, it could be concluded that taurine directly rescued mammary epithelial cells by decreasing the rates of apoptosis in order to maintain the capacity of the mammary glands to synthesize and store milk.

\section{Conclusions}

In general, heat stress significantly enhanced the translocation and expressions of HSF1 and the mRNA abundance of HSF90, to the point that a heat stress response was triggered. Furthermore, heat exposure-induced damage done to the mitochondria as well as oxidative stress were activated in the MAC-T cells. Then, exposure to oxidative stress induced the cell apoptosis. On the one hand, taurine effectively inhibited the translocation of HSF1 and the mRNA and the protein levels of HSF1 in order to improve the thermotolerance of the MAC-T cells. On the other hand, taurine relieved damage done to the mitochondrial structure and the decline in complex I activity, thereby rescuing the antioxidants activities. Finally, taurine reversed the rates of apoptosis in the HS-induced MAC-T cells (Figure 6). Therefore, this study provided useful evidence that taurine, as a novel natural additive, could possibly be used in cow feed under heat exposure.

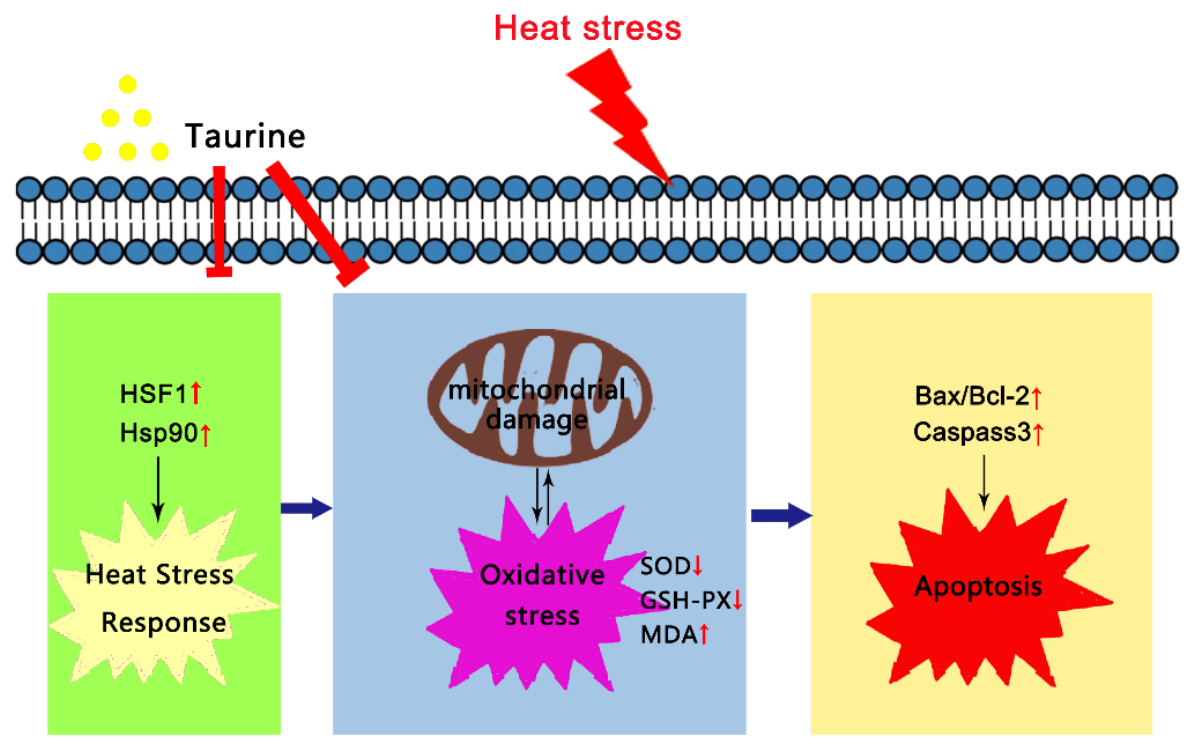

Figure 6. Taurine protected heat-induced MAC-T cells effectively by improving the thermotolerance of cells and reducing the levels of oxidative stress and cell apoptosis.

Author Contributions: Conceptualization: H.B. and P.Y.; Formal analysis: H.B. and H.K.; Investigation: H.B., T.L. and L.Y.; Resources: Y.Y. and Y.G.; Writing-original draft preparation: H.B.; Writing-review and editing: P.Y. and N.Z. All authors have read and agreed to the published version of the manuscript.

Funding: This study was supported by the National Key Research and Development Plan of China, grant number 2016YFD0500508.

Institutional Review Board Statement: Not applicable.

Informed Consent Statement: Not applicable. 
Data Availability Statement: Restrictions apply to the availability of these data.

Conflicts of Interest: The authors declare no conflict of interest.

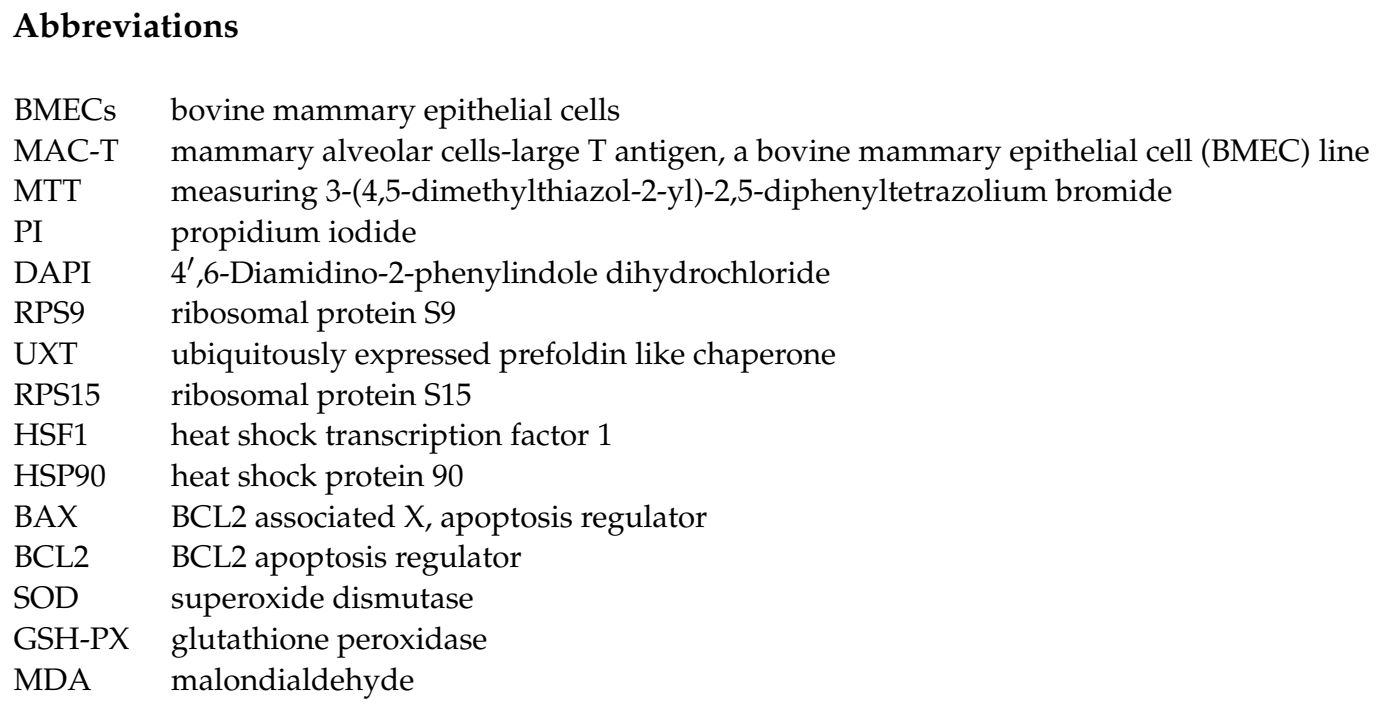

\section{References}

1. Sejian, V.; Bhatta, R.; Gaughan, J.B.; Dunshea, F.R.; Lacetera, N. Review: Adaptation of animals to heat stress. Animal 2018, 12, 431-444. [CrossRef] [PubMed]

2. Bernabucci, U.; Biffani, S.; Buggiotti, L.; Vitali, A.; Lacetera, N.; Nardone, A. The effects of heat stress in Italian Holstein dairy cattle. J. Dairy Sci. 2014, 97, 471-486. [CrossRef] [PubMed]

3. Nardone, A.; Ronchi, B.; Lacetera, N.; Ranieri, M.S.; Bernabucci, U. Effects of climate changes on animal production and sustainability of livestock systems. Livest. Sci. 2010, 130, 57-69. [CrossRef]

4. Hammami, H.; Bormann, J.; M'hamdi, N.; Montaldo, H.H.; Gengler, N. Evaluation of heat stress effects on production traits and somatic cell score of Holsteins in a temperate environment. J. Dairy Sci. 2013, 96, 1844-1855. [CrossRef] [PubMed]

5. Smith, D.L.; Smith, T.; Rude, B.J.; Ward, S.H. Short communication: Comparison of the effects of heat stress on milk and component yields and somatic cell score in Holstein and Jersey cows. J. Dairy Sci. 2013, 96, 3028-3033. [CrossRef] [PubMed]

6. Key, N.D.; Sneeringer, S.; Marquardt, D. Climate change, heat stress, and US. dairy production. Econ. Res. Rep. 2014. [CrossRef]

7. Tao, S.; Orellana, R.M.; Weng, X.; Marins, T.N.; Dahl, G.E.; Bernard, J.K. Symposium review: The influences of heat stress on bovine mammary gland function. J. Dairy Sci. 2018, 101, 5642-5654. [CrossRef]

8. Li, L.; Sun, Y.; Wu, J.; Li, X.; Luo, M.; Wang, G. The global effect of heat on gene expression in cultured bovine mammary epithelial cells. Cell Stress Chaperones 2015, 20, 381-389. [CrossRef]

9. Weng, X.; Monteiro, A.P.A.; Guo, J. Effects of heat stress and dietary zinc source on performance and mammary epithelial integrity of lactating dairy cows. J. Dairy Sci. 2018, 101, 2617-2630. [CrossRef]

10. Islam, M.A.; Noguchi, Y.; Taniguchi, S.; Yonekura, S. Protective effects of 5-Aminolevulinic acid on heat stress in bovine mammary epithelial cells. Asian Australas. J. Anim. Sci. 2020. [CrossRef]

11. Xiao, Y.; Rungruang, S.; Hall, L.W.; Collier, J.L.; Dunshea, F.R.; Collier, R.J. Effects of niacin and betaine on bovine mammary and uterine cells exposed to thermal shock in vitro. J. Dairy Sci. 2017, 100, 4025-4037. [CrossRef] [PubMed]

12. Salama, A.A.K.; Duque, M.; Wang, L.; Shahzad, K.; Olivera, M.; Loor, J.J. Enhanced supply of methionine or arginine alters mechanistic target of rapamycin signaling proteins, messenger RNA, and microRNA abundance in heat-stressed bovine mammary epithelial cells in vitro. J. Dairy Sci. 2019, 102, 2469-2480. [CrossRef]

13. Huxtable, R.J. Physiological actions of taurine. Physiol. Rev. 1992, 72, 101. [CrossRef] [PubMed]

14. Schaffer, S.; Azuma, J.; Takahashi, K.; Mozaffari, M. Why is taurine cytoprotective? Adv. Exp. Med. Biol. 2003, 526, 307. [PubMed]

15. Haider, S.; Sajid, I.; Batool, Z.; Madiha, S.; Khaliq, S. Supplementation of taurine insulates against oxidative stress, confers neuroprotection and attenuates memory impairment in noise stress exposed male Wistar rats. Neurochem. Res. 2020, 45, $2762-2774$. [CrossRef]

16. Cui, Y.; Wu, G.; Wang, Z.; Huang, F.; Ning, Z.; Chu, L.; Yang, S.; Lv, Q.; Hu, J. Effects of taurine on broiler aortic endothelial apoptosis induced by heat stress. Taurine 2019, 1155, 391-406.

17. Lak, S.; Ostadrahimi, A.; Nagili, B.; Asghari-Jafarabadi, M.; Djafarzadeh, R. Anti-inflammatory effect of taurine in burned patients. Adv. Pharm. Bull. 2015, 5, 531-536. [CrossRef]

18. Schuller-Levis, G.B.; Park, E. Taurine and its chloramine: Modulators of immunity. Neurochem. Res. 2004, 29, 117-126. [CrossRef]

19. Menzie, J.; Pan, C.; Prentice, H.; Wu, J.Y. Taurine and central nervous system disorders. Amino Acids 2014, 46, 31-46. [CrossRef] 
20. Bernabucci, U.; Lacetera, N.; Baumgard, L.H.; Rhoads, R.P.; Ronchi, B.; Nardone, A. Metabolic and hormonal acclimation to heat stress in domesticated ruminants. Animal 2010, 4, 1167-1183. [CrossRef]

21. Rhoads, M.L.; Kim, J.W.; Collier, R.J.; Crooker, B.A.; Boisclair, Y.R.; Baumgard, L.H.; Rhoads, R.P. Effects of heat stress and nutrition on lactating holstein cows: II. Aspects of hepatic growth hormone responsiveness. J. Dairy Sci. 2010, 93, 170-179. [CrossRef] [PubMed]

22. Hill, D.L.; Wall, E. Dairy cattle in a temperate climate: The effects of weather on milk yield and composition depend on management. Animal 2015, 9, 138-149. [CrossRef] [PubMed]

23. Li, C.; Wang, Y.; Li, L.; Han, Z.; Mao, S.; Wang, G. Betaine protects against heat exposure-induced oxidative stress and apoptosis in bovine mammary epithelial cells via regulation of ROS production. Cell Stress Chaperones 2019, 24, 453-460. [CrossRef] [PubMed]

24. Zou, Y.; Shao, J.; Li, Y.; Li, Y.; Zhao, F.; Liu, J.; Liu, H. Protective effects of inorganic and organic selenium on heat stress in bovine mammary epithelial cells. Oxidative Med. Cell. Longev. 2019, 2019, 1-10. [CrossRef]

25. Roy, A.; Sil, P.C. Tertiary butyl hydroperoxide induced oxidative damage in mice erythrocytes: Protection by taurine. Pathophysiology 2012, 19, 137-148. [CrossRef]

26. Rosa, F.T.; Freitas, E.C.; Deminice, R.; Jordo, A.A.; Marchini, J.S. Oxidative stress and inflammation in obesity after taurine supplementation: A double-blind, placebo-controlled study. Eur. J. Nutr. 2013, 53, 823-830. [CrossRef]

27. Li, M.; Reynolds, C.M.; Gray, C.; Patel, R.; Vickers, M.H. Long-term effects of a maternal high-fat: High-fructose diet on offspring growth and metabolism and impact of maternal taurine supplementation. J. Dev. Orig. Health Dis. 2019, 11, 419-426. [CrossRef]

28. Miao, J.; Fa, Y.; Gu, B.; Zhu, W.; Zou, S. Taurine attenuates lipopolysaccharide-induced disfunction in mouse mammary epithelial cells. Cytokine 2012, 59, 35-40. [CrossRef]

29. Li, Y.; Hu, Z.; Chen, B.; Bu, Q.; Lu, W.; Zhu, Y.; Deng, Y.; Shao, X.; Hou, J.; Zhao, J.; et al. Taurine attenuates methamphetamineinduced autophagy and apoptosis in PC12 cells through mTOR signaling pathway. Toxicol. Lett. 2012, 215, 1-7. [CrossRef]

30. Richter, K.; Haslbeck, M.; Buchner, J. The heat shock response: Life on the verge of death. Mol. Cell 2010, 40, 253-266. [CrossRef]

31. Hu, H.; Zhang, Y.; Zheng, N. The effect of heat stress on gene expression and synthesis of heat-shock and milk proteins in bovine mammary epithelial cells. Anim. Sci. J. 2016, 87, 84-91. [CrossRef] [PubMed]

32. Belal, S.A.; Kang, D.R.; Cho, E.S.R.; Park, G.; Shim, K. Taurine reduces heat stress by regulating the expression of heat shock proteins in broilers exposed to chronic heat. Braz. J. Poult. Sci. 2018, 20, 479-486. [CrossRef]

33. Cadenas, E.; Davies, K.J. Mitochondrial free radical generation, oxidative stress, and aging. Free Radic. Biol. Med. 2000, 29, 222-230. [CrossRef]

34. Lu, Z.; He, X.; Ma, B.; Lin, Z.; Li, J.; Yun, J.; Zhou, G.; Feng, G. Dietary taurine supplementation improves breast meat quality in chronic heat-stressed broilers via activating the Nrf2 pathway and protecting mitochondria from oxidative attack. J. Sci. Food Agric. 2019, 99, 1066-1072. [CrossRef] [PubMed]

35. Jong, C.J.; Azuma, J.; Schaffer, S. Mechanism underlying the antioxidant activity of taurine: Prevention of mitochondrial oxidant production. Amino Acids 2012, 42, 2223-2232. [CrossRef]

36. Belhadj Slimen, I.; Najar, T.; Ghram, A.; Abdrrabba, M. Heat stress effects on livestock: Molecular, cellular and metabolic aspects, a review. J. Anim. Physiol. Anim. Nutr. 2016, 100, 401-412. [CrossRef]

37. Gb, D. Biochemica and physiological changes during thermal stress in bovines. J. Vet. Sci. Technol. 2013, 3, 423-430. [CrossRef]

38. Aengwanich, W.; Kongbuntad, W.; Boonsorn, T. Effects of shade on physiological changes, oxidative stress, and total antioxidant power in Thai Brahman cattle. Int. J. Biometeorol. 2011, 55, 741-748. [CrossRef]

39. Balkan, J. Taurine has a protective effect against thioacetamide-induced liver cirrhosis by decreasing oxidative stress. Hum. Exp. Toxicol. 2001, 20, 251-254. [CrossRef]

40. Kirino, Y.; Yasukawa, T.; Ohta, S.; Akira, S.; Ishihara, K.; Watanabe, K. Codon-specific translational defect caused by a wobble modification deficiency in mutant tRNA from a human mitochondrial disease. Proc. Natl. Acad. Sci. USA 2004, 101, 15070-15075. [CrossRef]

41. Davies, K.J.A. The broad spectrum of responses to oxidants in proliferating cells: A new paradigm for oxidative stress. Iubmb Life 1999, 48, 41-47.

42. Qian, L.; Song, X.; Ren, H.; Jingbo, G.; Cheng, S. Mitochondrial mechanism of heat stress-induced injury in rat cardiomyocyte. Cell Stress Chaperones 2004, 9, 281-293. [CrossRef] [PubMed]

43. Liu, K.; Mao, X.; Li, H.; Liu, D.; Chen, X. Regulation of taurine in OTA-induced apoptosis and autophagy. Toxicon 2020, 181, 82-90. [CrossRef] [PubMed] 